\title{
Paths to Compliance: Enforcement, Management, and the European Union
}

\author{
Jonas Tallberg
}

In recent years, the question of what determines compliance with international regulatory agreements has gained an increasingly prominent position on the research agenda through a burgeoning literature on international regime effectiveness and international legal systems. The contemporary debate is framed in terms of two alternative perspectives on compliance: enforcement or management. The two perspectives present contending claims about the most effective means of addressing non-compliance in international cooperation. Whereas enforcement theorists characteristically stress a coercive strategy of monitoring and sanctions, management theorists embrace a problem-solving approach based on capacity building, rule interpretation, and transparency.

The two approaches are widely regarded as competing, both in theory and practice. Kal Raustiala and David Victor emphasize: "The two schools of thought reflect different visions of how the international system works, the possibilities for governance with international law, and the policy tools that are available and should be used to handle implementation problems." "Similarly, a recent review of compliance theory concludes: "[The debate between management and enforcement theorists] has deep roots; at its heart it reflects a fundamental division about the nature of law that permeates domestic as well as international jurisprudence."2

In this article, I challenge the conception of enforcement and management as competing strategies for achieving compliance. Based on the case of the European Union (EU) and a comparison with other international regimes, I find that enforce-

I thank Karen Alter, Tanja Börzel, Ole Elgström, Christer Jönsson, Ronald Mitchell, Charles Parker, Olav Schram Stokke, Arild Underdal, Oran Young, Michael Zürn, the anonymous reviewers, and the editors of $I O$ for valuable comments and helpful advice. I wrote the first version of the article while I was a research fellow at the Centre for Advanced Study, Oslo, within the research program on "Explaining International Regime Effectiveness."

1. Raustiala and Victor 1998, 681.

2. Raustiala and Slaughter 2002, 543.

International Organization 56, 3, Summer 2002, pp. 609-643

(C) 2002 by The IO Foundation and the Massachusetts Institute of Technology 
ment and management mechanisms are most effective when combined. ${ }^{3}$ In real-life international cooperation, the two strategies are complementary and mutually reinforcing, not discrete alternatives. Compliance systems that offer both forms of instruments tend to be particularly effective in securing rule conformance, whereas systems that only rely on one of the strategies often suffer in identifiable ways. In the same way, compliance systems that develop this complementarity over time demonstrate an enhanced capacity to handle non-compliance. These results are at odds with the claims of leading management and enforcement theorists, who explicitly denounce the merits of coercive and problem-solving strategies, respectively.

After a brief summary of the enforcement versus management debate, I develop my analysis in three stages. I begin by isolating the key elements of the EU compliance system, and explain how these interact to induce rule-conforming behavior. I describe how the EU compliance system consists of both centralized, active, and direct "police-patrol" supervision, conducted by the EU's supranational institutions, and decentralized, reactive, and indirect "fire-alarm" supervision, where national courts and societal watchdogs are engaged to induce state compliance. At both levels, the EU compliance system operates using a combination of enforcement and management mechanisms. This twinning of cooperative and coercive instruments in a "management-enforcement ladder" makes the EU exceedingly effective in combating detected violations, thereby reducing non-compliance to a temporal phenomenon.

Next, I focus on the sources of rule violations in the EU. I present data on the dominant forms of non-compliance in the EU and assess the explanatory power of the enforcement and management approaches, which privilege defection incentives and capacity limitations, respectively. Evidence from the literature on implementation in the EU supports both explanations, underscoring the complementary character of the two perspectives. In the EU, the primary sources of rule violations are incentives for defection associated with national adjustment to $\mathrm{EU}$ rules, and legislative and administrative capacity limitations in the member states.

In the concluding section, I place the EU compliance system in a comparative perspective and consider evidence from international regimes in the areas of trade, environment, and human rights. The international record lends support to the proposition that compliance systems are most effective when combining enforcement and management strategies. Where compliance systems have been supplemented with new or refined enforcement mechanisms, the effectiveness of preexisting managerial instruments has also been enhanced. What is particular about the EU's combination of enforcement and management strategies compared to other international regimes is that, in the EU, these functions are operated by independent supranational institutions and empowered societal interests. The supranational

3. I refer to the EU by its present name, except when I refer to its law, which is denoted European Community (EC) law. The numbering of treaty articles follows that of the consolidated treaties after the Amsterdam Treaty, with an article's former number in brackets the first time it is mentioned. 
organization serves the EU compliance system well, making it more effective in inducing compliance than interstate systems, where enforcement and management functions are executed by the signatories themselves. I conclude with a reflection on the preconditions of this supranational compliance system, and the probability of their emergence or creation elsewhere.

\section{The Compliance Debate: Enforcement versus Management}

In the last decade, contributions on regime compliance have increasingly left behind the realist-liberal debate on whether institutions matter. Instead, research has focused on identifying regime characteristics that are most conducive to eliciting compliance. The dominating perspectives in this contemporary debate are commonly referred to as the enforcement approach and the management approach. ${ }^{4}$ The two schools present contending claims about the sources of non-compliance and the most effective means for addressing this problem, thus creating strong counterexpectations.

\section{The Enforcement Approach}

The enforcement approach is firmly anchored in the political economy tradition of game theory and collective action theory. ${ }^{5}$ States are conceived of as rational actors that weigh the costs and benefits of alternative behavioral choices when making compliance decisions in cooperative situations. Both the sources of, and solutions to, non-compliance stem from the incentive structure. States choose to defect when confronted with an incentive structure in which the benefits of shirking exceed the costs of detection. Compliance problems are therefore best remedied by increasing the likelihood and costs of detection through monitoring and the threat of sanctions.

The proposition that states may willfully choose not to comply rests on the recognition that states' interests may include signature but not compliance. "Even if a state may believe that signing a treaty is in its best interest, the political calculations associated with the subsequent decision actually to comply with international agreements are distinct and quite different." question of priorities, given that compliance entails committing scarce resources that could be put to alternative uses. States may also decide to violate agreements because they do not value the actual contents of the rules, but consider the acts of participation and signing important.

4. These terms were first established in the exchange between Chayes and Chayes 1995; and Downs, Rocke, and Barsoom 1996.

5. See Olson 1965; Axelrod 1984; Axelrod and Keohane 1986; Yarbrough and Yarbrough 1992; Bayard and Elliott 1994; Downs, Rocke, and Barsoom 1996; Dorn and Fulton 1997.

6. Haas 1998, 19. On the calculus of compliance, see Young 1979; Underdal 1998. 
Enforcement theorists generally stress that the likelihood of intentional shirking is conditioned by the problem structure of the particular cooperative context. Collaboration - or mixed-motive-situations carry greater incentives to defect than coordination situations, where states experience every reason to cooperate in order to avoid common aversions. ${ }^{7}$ In collaboration situations, states have an incentive to renege on their commitments, since they gain more from an agreement if they reap all the benefits without putting in their own fair share. Since collaboration is the dominating problem structure in international regulation according to enforcement theorists, the problem of free riding is central to international cooperation.

For cooperation to generate collective benefits, enforcement is required to deter states from shirking. Monitoring and sanctions constitute the two central elements of this strategy. ${ }^{8}$ Monitoring increases transparency and exposes possible defectors. Sanctions raise the costs of shirking and make non-compliance a less attractive option. Together, monitoring and sanctions carry the capacity of deterring defections and compelling compliance. "A punishment strategy is sufficient to enforce a treaty when each side knows that if it cheats it will suffer enough from the punishment that the net benefit will not be positive."

In an influential contribution, George Downs, David Rocke, and Peter Barsoom extend this basic logic of the enforcement approach. ${ }^{10}$ Responding to the critique by managerial theorists that sanctions are seldom available or effective in international cooperation, Downs, Rocke, and Barsoom advance what might be dubbed the "depth-of-cooperation" hypothesis. The depth of cooperation refers to the extent to which a treaty requires states to depart from what they would have done in its absence. The depth of an agreement affects both the incentives for non-compliance and the need for enforcement. The more extensive the behavioral changes required by international rules, the greater are the incentives to shirk. By the same token, "the deeper the agreement is, the greater the punishments required to support it." "1

According to Downs, Rocke, and Barsoom, the limited use of sanctions at the international level can be explained by the fact that most treaties in operation today require only modest changes in state behavior. International agreements tend to codify existing behavior, rather than impose far-reaching adjustment requirements, and therefore confront states with few incentives to defect. The challenge by managerial theorists, therefore, is based on a skewed selection of cases and suffers from endogeneity problems. If, however, states were to negotiate agreements that require more profound behavioral changes, then enforcement would be imperative for securing compliance.

7. Stein 1983. For recent attempts to develop the notion of problem structure, see Mitchell 1999; Young 1999; Miles et al. 2002.

8. Olson 1965; Axelrod and Keohane 1986; Downs, Rocke, and Barsoom 1996; Dorn and Fulton 1997; Underdal 1998.

9. Downs, Rocke, and Barsoom 1996, 385.

10. Downs, Rocke, and Barsoom 1996.

11. Downs, Rocke, and Barsoom 1996, 386. 


\section{The Management Approach}

The management approach presents a perspective at odds with the claims of the enforcement school. ${ }^{12}$ Drawing on qualitative case studies, managerial theorists stress states' general propensity to comply with international rules, owing to considerations of efficiency, interests, and norms. Non-compliance, when it occurs, is not the result of deliberate decisions to violate treaties, but an effect of capacity limitations and rule ambiguity. By consequence, non-compliance is best addressed through a problem-solving strategy of capacity building, rule interpretation, and transparency, rather than through coercive enforcement.

Political and economic capacity limitations loom large in the managerial analysis of the sources of non-compliance. ${ }^{13}$ Oran Young declares: "The effectiveness of international institutions varies directly with the capacity of the governments of members to implement their provisions." 14 Political capacity limitations arise when a government lacks the ability to ensure that public and private actors meet international commitments. The government may be unable to secure ratification, command compliance from subnational entities, or muster the necessary administrative capacity. Economic capacity problems arise when financial constraints impinge on a state's ability to fulfill international obligations. Resource limitations may directly hamper compliance efforts, and macroeconomic factors may be important indirectly, by setting the economic and political framework within which public and private actors operate.

Managerial theorists further suggest that non-compliance may be inadvertent. ${ }^{15}$ For a number of reasons, treaty language is often unclear and imprecise, which leads to misinterpretation by states. "[M]ore often than not there will be a considerable range within which parties may reasonably adopt differing positions as to the meaning of the relevant treaty language." ${ }^{\prime 6}$ Inadvertent non-compliance may also result from the uncertainty involved in choosing the policy strategies required to meet a certain treaty target, for instance, in the environmental field.

This diagnosis of the causes of non-compliance translates into a competing perspective on the means to address violations. In an influential contribution, Abram Chayes and Antonia Handler Chayes emphasize: "If we are correct that the principal source of noncompliance is not willful disobedience but the lack of capability or clarity or priority, then coercive enforcement is as misguided as it is costly." ${ }^{17}$ The prominence of such instruments in research by enforcement theorists does not reflect their actual use and success, argue Chayes and Chayes: "Sanctioning authority is

12. See Young 1992; Haas, Keohane, and Levy 1993; Mitchell 1994; Chayes and Chayes 1995; Keohane and Levy 1996; Chayes, Chayes, and Mitchell 1998.

13. Young 1992; Levy, Keohane, and Haas 1993; Chayes and Chayes 1995; Jacobson and Brown Weiss 1998.

14. Young 1992, 183.

15. See Mitchell 1994; Chayes and Chayes 1995; Chayes, Chayes, and Mitchell 1998.

16. Chayes and Chayes 1995, 11 .

17. Chayes and Chayes $1995,22$. 
rarely granted by treaty, rarely used when granted, and likely to be ineffective when used." 18

Instead, managerial theorists privilege capacity building, rule interpretation, and transparency as cures for non-compliance. ${ }^{19}$ Whereas some political and economic capacity problems are beyond the reach of international efforts, deficits in technical knowledge, bureaucratic capability, and financial resources may be partially or entirely offset through capacity building. Often, capacity building is one of the main programmatic activities of international regimes; in other cases, technical and financial assistance is a targeted measure to alleviate a particular problem.

To reduce compliance problems resulting from ambiguous treaty language, the management approach suggests authoritative rule interpretation in international legal bodies. In this line of theorizing, dispute settlement is primarily viewed as clarifying common norms through interpretation and adjudication, rather than providing enforcement. The mechanisms of rule interpretation need not be formal adjudication in international courts; informal and non-binding mediative processes can also clarify treaty rules.

Transparency, the third privileged cure, improves compliance by facilitating coordination on the treaty norms, providing reassurance to actors that they are not being taken advantage of, and raising the awareness of the effects of alternative national strategies. Transparency is thereby linked to the managerial strategy of convincing miscreants to change their behavior through social pressure, rather than through coercive measures.

\section{Enforcement and Management in the EU}

The design and operation of the EU's system for inducing compliance challenges the antithetical positioning of enforcement and management strategies in the contemporary debate. In the EU, monitoring, sanctions, capacity building, rule interpretation, and social pressure coexist as means for making states comply. In the daily practice of the EU compliance system, these instruments are mutually reinforcing, demonstrating the merits of combining coercive and problem-solving strategies. In the following section, I describe the operation of this strategic combination at two levels: the centralized system managed by the EU's supranational institutions, and the decentralized system composed of individuals securing their EU rights in national courts.

\section{The EU Institutions and the Centralized Compliance System}

The primary means to come to terms with rule violations in the $E U$ is the compliance system at the centralized EU level, where the EU institutions hold states

18. Chayes and Chayes 1995, 32-33.

19. See Young 1992 and 1999; Levy, Keohane, and Haas 1993; Mitchell 1994; Chayes and Chayes 1995; Chayes, Chayes, and Mitchell 1998; Haas 1998; Jacobson and Brown Weiss 1998; Mitchell 2000. 
responsible for their violations, but also attempt to improve their capacity to comply. Much like the U.S. Congress in Mathew McCubbins and Thomas Schwartz's classic example of "police-patrol" supervision, the European Commission (the Commission) and the European Court of Justice (ECJ), at their own initiative, monitor compliance, remedy violations, and discourage further breaches. ${ }^{20}$ The management and enforcement mechanisms at this centralized level form a ladder of measures, consisting of preventive capacity building and rule interpretation, systems of monitoring, legal proceedings against violators, informal channels of bargaining, and the final option of sanctions.

At the level of violation prevention, the EU institutions seek to compensate for capacity deficiencies and provide positive inducements through a range of management measures. Four strategies are particularly prominent. First, the EU has sought to improve member states' ability to comply through a set of economic funds that ease and encourage adjustment to EU policy. The LIFE fund facilitates conformity with EU environmental policy through support in the area of environmental protection, and the European Regional Development Fund (ERDF) and the European Social Fund (ESF) target the need for structural adjustment in regions suffering particularly from internal market liberalization. Second, the Commission negotiates transitional arrangements with states acceding to the EU to allow them additional time to adjust to new behavioral requirements. The two most recent enlargement rounds illustrate that transitional arrangements are used both in cases where an acceding country has particularly strong and diverging interests in a policy area (for example, Sweden's state monopoly on the import and retail of alcoholic beverages), and where a state is subject to intense adjustment demands in a policy area and must be allowed time to prepare for full participation (for example, Spain, Portugal, and the internal market).

Third, the Commission seeks to close knowledge gaps within, and promote trust between, national authorities charged with applying and enforcing internal market rules. In the period 1993-1999, the Karolus program financed the exchange of national officials, and as of 1999, an extensive program on "administrative cooperation" promotes decentralized problem solving through a network of coordination centers and contact points. Fourth, the Commission issues interpretative guidelines in policy issues where rule uncertainty has given rise to unnecessary non-compliance. The delicate relationship between internal market rules and environmental objectives is one such area, where the Commission seeks to clarify the standing of existing EC law through interpretative statements and case-based guidelines.

To induce compliance once violations have occurred, the principal instrument is the infringement procedure under Article 226 (ex. Art. 169), where the Commission functions as prosecutor and the ECJ as judge. ${ }^{21}$ The treaties also provide for a procedure under Article 227 (ex. Art. 170), whereby member states may take action

20. McCubbins and Schwartz 1984.

21. On the operation of this system, see Audretsch 1986; Snyder 1993; Mendrinou 1996; Tallberg 1999a; Börzel 2001 


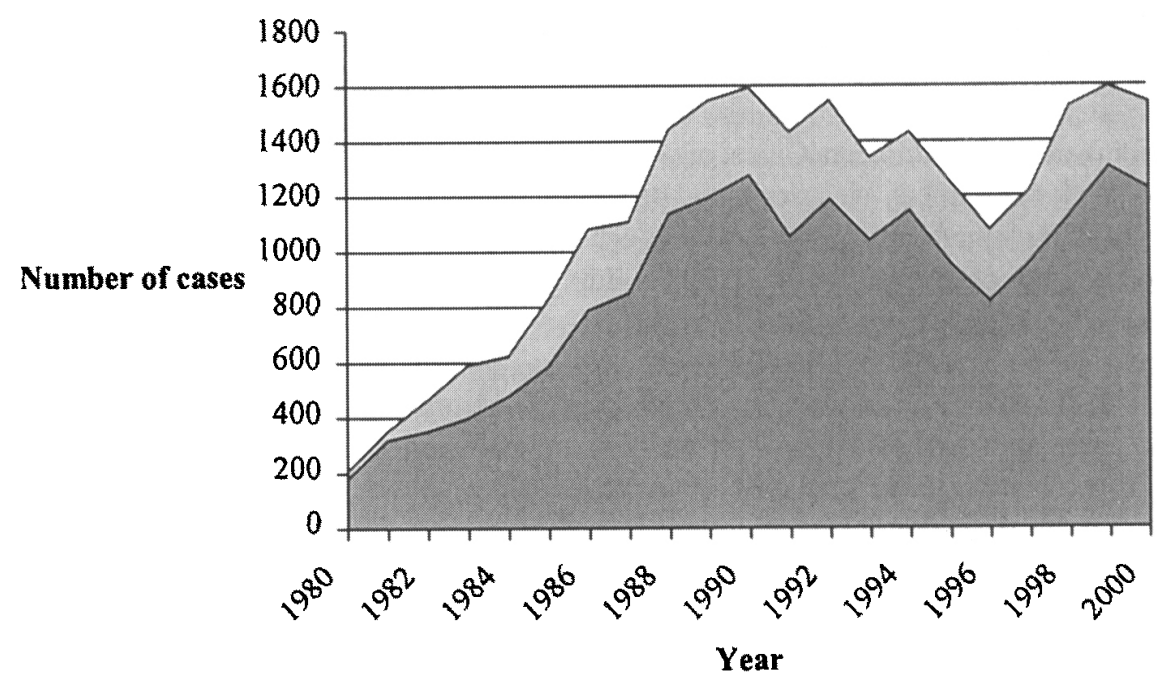

Complaints $\square$ Commission inquiries

FIGURE 1. Origin of cases of suspected infringements 1980-2000

Source: European Commission annual monitoring reports.

Note: In 1990, the Commission started reporting petitions to, and questions asked by, the European Parliament as a separate source of suspected infringements. I include these petitions and questions in the category "Commission inquiries," since this is where the Commission itself chooses to place them in the later part of this period. In 1995, the Commission introduced yet another category: failure to report measures taken to implement EU directives. Because the Commission does not indicate whether this is a new source of information, or whether it has always acted on this information without reporting it as a source, $I$ do not include this category in the figure. I report it as follows: 459 (1995), 1079 (1996), $760(1997), 610(1998), 677(1999), 896$ (2000).

against each other for breaches of EU rules. This procedure has been used extremely rarely, however, since member states prefer the Commission to take the charge, in view of the costs of litigation, the risk of retaliation, the diplomatic inconvenience, and the greater acceptability of proceedings initiated by a neutral institution.

To detect violations, the Commission monitors member state conformity with $\mathrm{EU}$ rules, following a two-track approach. On the one hand, it actively and systematically collects and assesses information on state compliance through in-house monitoring. On the other hand, the Commission operates an informal procedure through which it records and examines complaints lodged by citizens, firms, nongovernmental organizations, and national administrations. The complaint procedure offers a form of monitoring that is more resource-efficient than systematic in-house inquiries, provides access to information otherwise unobtainable, and points to areas of EU legislation that may be particularly ambiguous and in need of clarification. Figure 1 depicts the development of complaints and the Commission's 
own inquiries as sources of cases identified as suspected infringements of EU rules. The figure shows a system of monitoring that is largely complaint-based. The key factors behind the growing gap are steps taken by the Commission to boost complaints as a means of monitoring, in view of its own internal resource limitations, as well as popular grievance about state non-compliance with internal market rules. $^{22}$

The formal initiation of an infringement proceeding is preceded by informal consultations between the Commission and the state suspected of violations. These consultations weed out cases that may have arisen due to legal uncertainty and misunderstandings. Inadvertent violations are thereby effectively removed at an early stage. For the remaining cases, the process continues by way of formal means. The Article 226 infringement procedure consists of three formal stages: the Commission's initiation of a proceeding through a "letter of formal notice," the Commission's legal elaboration through a "reasoned opinion," and the Commission's referral of a case to the ECJ for a final decision.

Within the formal framework of the infringement procedure, enforcement and management processes serve to turn up the pressure, making compliance an increasingly attractive option for member states. "When the State appears to persist in the violation, an attempt will be made to raise the cost of violation or to lower its profit." 23 This takes a number of forms. In its communication with member governments, the Commission declares its readiness to eventually use economic sanctions against them. Social costs are imposed through an explicit Commission strategy to "name and shame" non-compliant member states, most concretely, by issuing incriminating press releases and publishing scoreboards on state violations. Finally, the Commission exploits both its unilateral power to bring cases to the next stage in the procedure and the fact that "no member state wants to have infringement proceedings in front of the Court of Justice against it" ${ }^{24}$ by threatening further steps if member states do not yield.

The escalation of pressure and the shared interest to avoid costly and resourceconsuming litigation provides for an environment highly hospitable to bargaining between the Commission and member states. Negotiated solutions have therefore become a prominent way of closing infringement cases before they reach the ECJ. As Francis Snyder eloquently states: "We usually think of negotiation and adjudication as alternative forms of dispute settlement. It may be suggested, however, that in the daily practice and working ideology of the Commission, the two are not alternatives but instead are complementary. The main form of dispute settlement used by the Commission is negotiation, and litigation is simply a part, sometimes inevitable but nevertheless generally a minor part, of this process." 25

22. Tallberg 1999a.

23. Audretsch 1986, 410 .

24. Interview, European Commission official, September 1996.

25. Snyder 1993, 30. See also Mendrinou 1996; Jönsson and Tallberg 1998. 
TABLE 1. Infringement cases per member state by stage, 1978-2000

\begin{tabular}{lccrrr}
\hline \multicolumn{1}{c}{ State } & Formal notice & \multicolumn{2}{c}{ Reasoned } & opinion & \multicolumn{2}{c}{ ECJ referral } \\
\hline Belgium & 1,443 & 652 & $45.2 \%$ & 236 & $16.4 \%$ \\
Denmark & 779 & 103 & $13.2 \%$ & 22 & $2.8 \%$ \\
Germany & 1,352 & 517 & $38.2 \%$ & 136 & $10.1 \%$ \\
Greece & 1,611 & 659 & $40.9 \%$ & 198 & $12.3 \%$ \\
France & 1,772 & 721 & $40.7 \%$ & 234 & $13.2 \%$ \\
Ireland & 1,143 & 405 & $35.4 \%$ & 121 & $10.6 \%$ \\
Italy & 1,970 & 1,010 & $51.4 \%$ & 396 & $20.1 \%$ \\
Luxembourg & 1,083 & 409 & $37.8 \%$ & 130 & $12.0 \%$ \\
Netherlands & 1,021 & 288 & $28.2 \%$ & 72 & $7.1 \%$ \\
Portugal & 1,230 & 483 & $39.3 \%$ & 63 & $5.1 \%$ \\
Spain & 1,048 & 349 & $33.3 \%$ & 74 & $7.1 \%$ \\
U.K. & 1,125 & 304 & $27.0 \%$ & 50 & $4.4 \%$ \\
EU 12 & 15,577 & 5,900 & $37.9 \%$ & 1,737 & $11.2 \%$ \\
& & & & & \\
\hline
\end{tabular}

Source: European Commission annual monitoring reports.

Once a case has been referred to the ECJ, the room for bargaining is significantly reduced. It is not uncommon, however, that member states get cold feet when faced with the prospect of a negative judgment. The possibility is very real: about 90 percent of all infringement judgments are in favor of the Commission. ${ }^{26}$ In addition, ECJ judgments tend to arouse greater interest among other member states and the public at large than preliminary proceedings, further raising the social costs of non-compliance. The ECJ's infringement judgments also fulfill the managerial function of reducing the legal uncertainty of EU rules, by clarifying the treaties and providing precedents for future disputes.

The effect of these combined enforcement and management measures is a sharp reduction of violations from one step in the infringement procedure to the next, as Table 1 demonstrates. Of the total number of infringement proceedings initiated between 1978 and 2000 , only 38 percent reached the stage of reasoned opinions, and only 11 percent were referred to the ECJ. All member states display the same preference for backing down or finding amicable solutions at the early stages of the infringement procedure. Yet some states, such as Denmark, the U.K., the Netherlands, and Spain, go to great lengths to settle cases as early as possible; others, such as Italy, Belgium, Greece, and France, tend to persist in their violations and end up having a higher share of cases referred to the ECJ.

Previously, if states disregarded ECJ judgments the only measure available was renewed infringement proceedings. Since the entry into force of the Treaty on European Union (TEU) in 1993, however, the EU's supranational institutions may 
TABLE 2. Infringement cases closed in 1999 by stage in the procedures

\begin{tabular}{lrc}
\hline \multicolumn{1}{c}{ Stage } & Number & Percentage \\
\hline Before formal notice & 763 & $40.2 \%$ \\
Before reasoned opinion & 593 & $31.2 \%$ \\
Before ECJ referral & 435 & $22.9 \%$ \\
Before ECJ judgment & 40 & $2.1 \%$ \\
Before second formal notice & 46 & $2.4 \%$ \\
Before second reasoned opinion & 12 & $0.6 \%$ \\
Before second ECJ referral & 10 & $0.5 \%$ \\
Before ECJ sanctioning judgment & 1 & $0.1 \%$ \\
TOTAL & 1,900 & $100.0 \%$ \\
\hline
\end{tabular}

Source: European Commission 2000.

impose economic penalties under the Article 228 (ex. Art. 171) sanctioning procedure. The sanctioning procedure consists of the same three stages as the infringement procedure, but with the possibility of penalty payments as a final measure. Penalties are proposed by the Commission and decided by the ECJ.

The Commission has explicitly designed the sanction as an instrument of deterrence, involving daily penalty payments at punitive levels. ${ }^{27}$

Decisions as to the amount of the penalty must be taken with an eye to its actual purpose, which is to ensure that Community law is effectively enforced. [ ...] Once it has been found that a penalty should be imposed, for it to have a deterrent effect it must be set at a higher figure if there is any risk of repetition (or where there has been a repetition) of the failure to comply, in order to cancel out any economic advantage which the Member State responsible for the infringement might derive in the case in point. ${ }^{28}$

The Commission made use of the new sanctioning power for the first time in January 1997, and during the period 1997-2000 it proposed penalties in 21 cases-the amounts ranging from 6,000 to 264,000 euro per day. ${ }^{29}$ The unequivocal picture is one of a highly deterrent mechanism. Member states have been quick to back down in the face of the sanctioning threat. In only one case have the Commission and the ECJ been forced to actually impose the proposed penalties (Greek waste-dumping in Crete).

Table 2 provides a snapshot of the closure of cases at various stages of the infringement and sanctioning procedures in one given year (1999). Of 1,900 cases closed, as many as 95 percent were solved before referral to the ECJ. The table

28. European Commission 1996c, 2-3.

29. European Commission 1999, 2000, and 2001. 
further demonstrates how the successive reduction in violations continues even after referral. Member states back down before judgment, after a court decision, when charged with the non-implementation of a judgment, or, ultimately, when confronted with the threat of sanctions. These data suggest that non-compliance in the $\mathrm{EU}$ is a temporal phenomenon. While reasonably common, violations of EU rules are seldom protracted, owing to the combined effect of enforcement and management mechanisms.

Whereas delegated powers set the framework for the centralized compliance system, the Commission has played an independent part in developing this structure. It is widely acknowledged that the Commission was pivotal in making capacitybuilding funds one of the EU's main programmatic activities. ${ }^{30}$ Less known are the measures the Commission took in the 1990 s to reinforce the capacity of the infringement procedure to secure rule-observing behavior. ${ }^{31}$ Slightly simplified, the Commission streamlined the internal handling of infringement cases, completed the shift toward a semi-automatic initiation of infringement proceedings, integrated the threat of penalty payments in its supervision policy, and boosted complaints as a source of information. In addition, the Commission developed its shaming strategy by publishing regular reports on member state infringements, and institutionalized compliance bargaining by introducing a procedure whereby cases are reviewed in direct negotiations with state representatives. Taken together, these measures reinforce the compliance-inducing capacity of the centralized compliance system.

\section{Individuals, National Courts, and the Decentralized Compliance System}

In addition to the means at the centralized level, a decentralized compliance system has evolved in the EU, where individuals and companies are engaged as "fire alarms" that monitor state behavior, clarify EC law, and sanction non-compliance. Like the U.S. Congress in McCubbins and Schwartz's example, the role of the EU institutions consists of providing the framework conditions necessary for this decentralized system to function properly. ${ }^{32}$

The building blocks of this structure were laid down with the ECJ's creative establishment of the principles of direct effect and EC law supremacy in the early 1960s. The principle of direct effect posited that EC law created legally enforceable rights for individuals, allowing them to invoke European provisions directly before national courts. The principle of EC law supremacy stipulated that Community law "trumps" national law when in conflict. Through these doctrines, the ECJ turned the preliminary ruling system under Article 234 (ex. Art. 177) from a mechanism that

30. See Marks 1993; Hooghe 1996.

31. For an extensive account, see Tallberg 1999a.

32. McCubbins and Schwartz 1984. 
allowed individuals to challenge EC law in national courts into a means for challenging national law and securing EC law in national courts. ${ }^{33}$

After initial opposition among many national courts, these principles became increasingly accepted, and national courts began to protect the EC rights of individuals and to refer cases to the ECJ when interpretive uncertainty so demanded. ${ }^{34}$ From a very limited number of preliminary references yearly in the 1960s, these increased to around 50 in the mid-1970s, slightly over 100 in the early $1980 \mathrm{~s}$, and close to 200 around $1990 .{ }^{35}$ National courts thus became the linchpins of the European legal system and entered into a symbiotic relationship with the ECJ. A functional division was established, where the ECJ interprets and national courts apply EC law. This system has now been in operation for almost four decades, and it is generally recognized that national courts today perform dual duties and simultaneously enforce two bodies of law: the European and the national.

The decentralized compliance system fulfills both enforcement and management functions. It allows private parties with a stake in EU rules to sue national governments for non-compliance in their own courts. Today this also carries the threat of financial sanctions against member states, as individuals are entitled to compensation for losses suffered as a result of state non-compliance. The social costs of violations are less pronounced than at the centralized level, since national court judgments seldom arouse widespread interest in the country concerned, and even less so in other member states. The referral of cases to the ECJ for interpretation serves the function of elucidating EC law, reducing ambiguity, and building precedent. It thereby reduces the risk of inadvertent non-compliance.

The effectiveness of this decentralized system in inducing state compliance is exceedingly difficult to measure in quantitative terms. While data on preliminary references are available, this measure has clear limitations as an indicator of non-compliance. Lower national courts need only refer cases to the ECJ when existing EC law is deemed not to provide sufficient guidance for the national court to decide the matter and enforce compliance itself. In practice, this means that the data on preliminary references fail to capture much of the compliance-inducing activity of national courts. ${ }^{36}$ Without satisfactory quantitative data, the literature on decentralized enforcement in the EU has proceeded mainly by way of qualitative case studies. These studies provide ample demonstrations of how individuals, interest groups, and corporate actors, through legal actions in national courts, have pressured national governments into compliance with EC law. ${ }^{37}$

33. See Stein 1981; Weiler 1991.

34. See Weiler 1991; Burley and Mattli 1993; Slaughter, Stone Sweet, and Weiler 1998; Alter 2001 a.

35. Stone Sweet and Brunell 1998.

36. In addition, references from national courts to the ECJ are sometimes motivated by other concerns than national non-compliance with European legal measures. Alter 2000, 500.

37. See Harlow and Rawlings 1992; Aiter and Vargas 2000, Cichowski 2002; Conant 2002. 
From the perspective of the EU institutions, the decentralized structure carries a set of advantages, mirroring the general merits of "fire-alarm" oversight. ${ }^{38}$ It shifts the costs of supervision to individuals and national courts, thereby alleviating some of the burden placed on the Commission and the ECJ. It permits closer monitoring of state compliance on the ground. Finally, it allows individuals to secure their rights under EC law more directly and with greater likelihood of judgments being respected, since governments generally experience great difficulties disregarding decisions of their own national courts. ${ }^{39}$

Acting on these advantages, the EU institutions have played a prominent role in developing the decentralized compliance system. After the ECJ's creative engineering in the 1960s, and certain improvements during the 1970s, the period from the mid-1980s witnessed determined efforts by the Commission and the ECJ to boost the system's compliance-inducing capacity. ${ }^{40}$ The ECJ's efforts were focused on the remedies available to citizens and companies wishing to safeguard rights granted by EU rules. In a string of groundbreaking decisions, the ECJ laid down principles and requirements for the remedies and procedures that should be available in national courts in matters related to EC law. ${ }^{41}$ The culmination of the ECJ's campaign was its judgment in Francovich, where a completely new damages remedy was created - state liability - granting individuals and companies the right to financial compensation from non-compliant member states. In effect, the principle of state liability established a form of decentralized sanctions that member governments themselves had decided against. ${ }^{42}$ This boosting of legal remedies in general, and the establishment of state liability in particular, stands out as a third stage in the judicial construction of decentralized enforcement, after the initial development of the doctrines of direct and indirect effect and EC law supremacy. ${ }^{43}$

In parallel to the ECJ's activities, the Commission launched a number of policy initiatives aimed at perfecting this structure. Two programs were particularly important in reducing weaknesses in the existing system. The Citizens First initiative, the most ambitious information program ever undertaken by the Commission, sought to encourage citizens and companies to secure their EU rights in national courts. Following a two-track approach, the initiative raised citizens' awareness of their rights under EC law, and informed them of how they could go about safeguarding these rights and be awarded compensation. The Robert Schuman

38. McCubbins and Schwartz 1984.

39. Weiler 1994.

40. Tallberg 1999a.

41. For example, Von Colson and Kamann v. Land Nordrhein-Westfalen, Case 14/83, ECR 1984: 1891. Factortame v. Secretary of State for Transport, Case C-213/89, ECR 1990: 2433. Zuckerfabrik Süderdithmarschen AG v. Hauptzollamt Itzehoe, Joined Cases C-143/88 and C-92/89, ECR 1991 (1): 415. Emmott v. Minister for Social Welfare, Case C-208/90, ECR 1991 (1): 4269. Francovich and Others v. Italy, Joined Cases C-6 and 9/90, ECR 1991 (1): 5357. Marshall v. Southampton and South West Hampshire Health Authority, Case C-271/91, ECR 1993 (1): 4367.

42. Tallberg $2000 \mathrm{a}$.

43. See Steiner 1995, chap. 2; Dehousse 1998, 46. 
program targeted a second cognitive weakness of the decentralized system: insufficient knowledge of EC law in the legal professions. In the Commission's reasoning, national judges and lawyers would be unable to secure individuals' rights and ensure compliance, unless they had a sufficiently developed awareness of the contents of those rights and rules. Together, these policy programs mended gaps in a decentralized compliance system essentially engineered by the ECJ.

\section{Sources of Non-compliance in the EU}

In the previous section, I demonstrated how the combination of enforcement and management strategies in the EU induces governments to step into line once violations have been detected. In this section, I shift attention to the sources of these violations. What causes non-compliance? Assessing evidence generated in the literature on implementation in the EU, I find support for the privileged explanations of both the enforcement approach and the management approach. Non-compliance in the EU can best be explained by incentives for defection associated with national adjustment to EU rules, and legislative and administrative capacity limitations in the member states. This finding underscores the complementary character of the enforcement and management approaches, and suggests why both coercive and cooperative strategies are required to deal with non-compliance. The section begins with an exploration of the dominant forms of non-compliance in the EU.

\section{Non-compliance in the $E U$}

Non-compliance with EU rules may be grouped in two broad categories. The first category consists of failures to legally implement directives correctly and on time. Directives constitute the primary instrument for harmonizing European policies. For directives to enter into effect, they must first be legally implemented in the member states, which requires the adoption of new legislative acts, the amendment of existing law, or the repeal of provisions preventing the accomplishment of a directive's objectives. Normally, the deadline for implementation imposed by the EU's Council of Ministers is two years. The second category of violations consists of non-compliance in the application of EU rules. The essence of European policies is the operation of these rules in the member states. Directives that have been legally implemented must be correctly applied, and member state behavior must conform to the rules laid down by treaty articles, regulations, and decisions (which do not require national implementing measures). These two forms of violations conform to general conceptualizations of non-compliance in the literature on regime effectiveness. This literature distinguishes between "measures that states take to make international accords effective in their domestic law," on the one hand, and "whether 


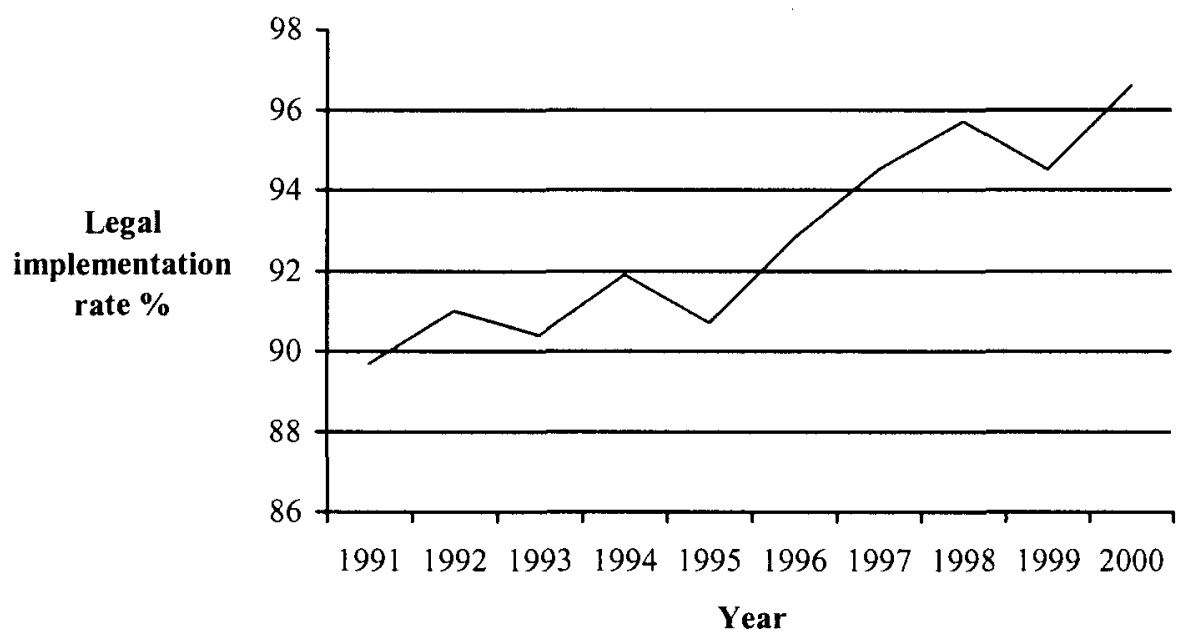

FIGURE 2. EU rate of legal implementation (directives) 1991-2000

Source: European Commission annual monitoring reports.

countries in fact adhere to the provisions of the accord and to the implementing measures they have instituted," on the other. ${ }^{44}$

Data published by the Commission show that both forms of non-compliance are common in the EU. Direct measures of the degree of compliance only exist with regard to legal implementation, since the application of EU rules on the ground is exceedingly difficult to monitor and evaluate. Figure 2 tracks the evolution of the rate of legal implementation of directives in the 1990s. Implementation has improved over time, from a level of around 90 percent to about 96 percent. The share of implemented directives is high, but must be seen in context. A backlog of 5 to 10 percent means that each member state, on average, has had seventy-five to one hundred directives left to implement by the end of each year. This is a nonnegligible number in a Union where only thirty to seventy directives are adopted each year. ${ }^{45} \mathrm{~A}$ disaggregation of the EU figure reveals a pattern of cross-national variation, where Italy, Portugal, and Greece tend to fall short of the EU average, while Denmark, the Netherlands, and the U.K. are distinguished by particularly high levels of implementation.

The infringement proceedings initiated by the Commission against member states are an indirect measure of the two forms of non-compliance. The weeding out before formal initiation of cases caused by misunderstanding guarantees only cases of 


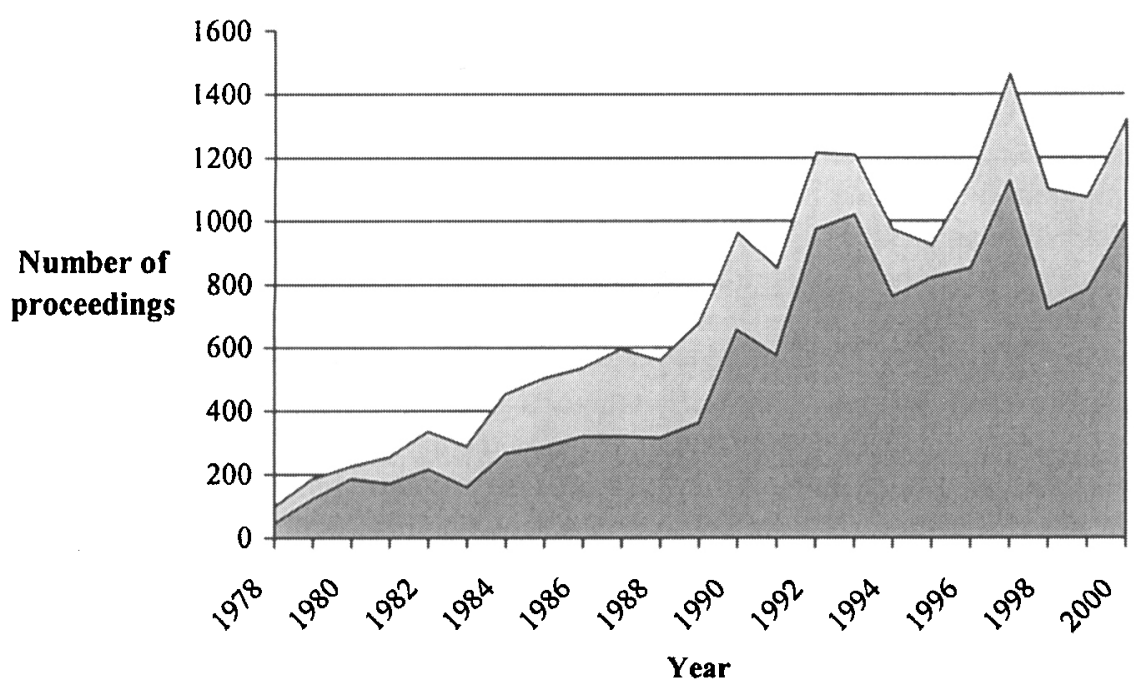

Implementation failure $\square$ Application failure

FIGURE 3. Infringement proceedings initiated for non-compliance with EU rules $1978-2000$

Source: European Commission annual monitoring reports.

strongly suspected violations result in proceedings. ${ }^{46}$ Figure 3 shows the annual number of proceedings during the period 1978-2000, and distinguishes between the two alternative reasons for initiation. It demonstrates that a large majority of infringement proceedings are initiated because of state failure to implement directives correctly and on time. The high frequency of implementation failure as the source of proceedings should be understood in view of the greater ease with which such violations are identified compared to faulty application of rules on the ground. In this respect, Figures 2 and 3 are not unrelated; the Commission's persistent initiation of proceedings against implementation failure is one of the reasons why the EU implementation rate has risen in recent years. In addition, the share of proceedings initiated for implementation failure declines relative to application failure as we proceed through the steps of the infringement procedure, suggesting that the first form of non-compliance is easier to remedy.

Figure 3 further shows how the number of proceedings has gradually climbed over time, with a sharp increase in the first half of the 1990s, when member states

46. ECJ judgments, which formally establish non-compliance, are a less useful indicator of actual compliance problems, since states often yield to Commission pressure during the course of proceedings, and do so to varying extents, as demonstrated in the previous section. 
were confronted with the challenge of implementing the internal market program. In the $1990 \mathrm{~s}$, the Commission often initiated over 1,000 proceedings annually, and in 1997 the figure even exceeded 1,400. Comparable estimates for national political systems or other international regimes do not exist, although a total of 228 complaints were made to the World Trade Organization (WTO) between January 1995 and March 2001. ${ }^{47}$

This cross-temporal pattern must be interpreted with care. ${ }^{48}$ On the one hand, the growth over time in the body of EC law, the increasing number of member states, and the introduction of more aggressive enforcement practices in the Commission function as upward biases on cross-temporal patterns. On the other hand, resource limitations in the Commission put a ceiling on the institution's capacity to follow up on violations, which caps the effects of these upward biases on the number of initiated proceedings. These factors, and the difficulties involved in controlling for their combined effect, call for caution when drawing inferences about changes in compliance from variation over time in the number of infringement proceedings. Cross-temporal patterns in proceedings are most reliable as evidence when restricted to limited time periods in specific sectors or for particular member states. It is in this capacity that I draw on them in the following analysis of the sources of noncompliance.

Cross-national patterns in infringement cases are not subject to the same problem of external biases. There is no evidence that the Commission is systematically discriminating among member states in the initiation of infringement proceedings. Cross-national patterns can therefore be directly linked to variation in national rates of compliance. Figure 4 shows the average yearly number of infringement proceedings per member state over the period 1978-2000. Member states display clear patterns in non-compliance, with limited variation in the internal ranking over time. The most compliant state is Denmark, followed by the Netherlands, Luxembourg, the U.K., Ireland, and Germany. Above the EU average, we find Belgium, Spain, France, Greece, Portugal, and Italy. ${ }^{49}$

In the following section, I suggest that defection incentives and capacity limitations are the two primary causes of these forms and patterns of non-compliance. In their official rhetoric, governments tend to blame violations on factors or actors beyond their control. To clearly separate preference- and capacity-driven noncompliance, I reserve the latter for situations where the central government is unable to unilaterally ensure national conformity with EU rules, for instance, because of subnational legislative prerogatives. By contrast, I define situations where the government considers itself "unable" to comply, for instance, because of interest group pressure, but nevertheless retains the ultimate decision-making power, as preference-driven.

47. World Trade Organization 2001.

48. For a cautionary note, see Börzel 2001. On variation in the Commission's enforcement practices, see Tallberg 1999a.

49. Austria, Finland, and Sweden are excluded because they joined the EU in only 1995. 


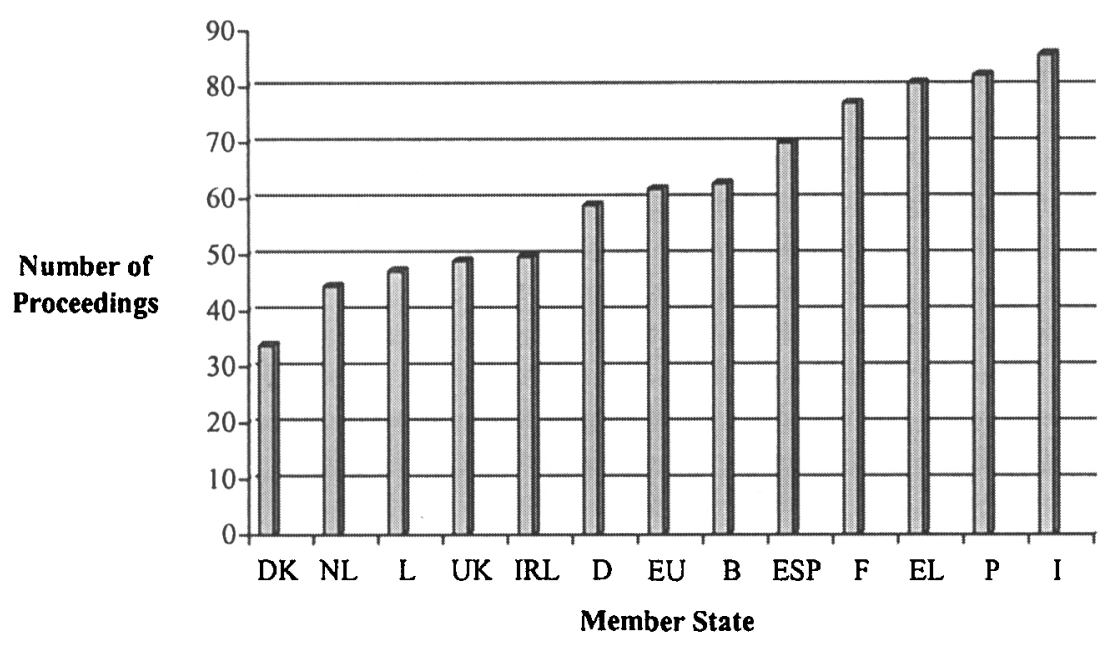

FIGURE 4. Infringement proceedings initiated per member state, yearly average $1978-2000$

Source: European Commission annual monitoring reports.

\section{Non-compliance as a Preference}

Existing research on national adaptation to EU rules grants firm support for the propositions advanced by the enforcement approach on the causes of non-compliance. The behavioral adjustments required by EU rules, and associated incentives for shirking, constitute a powerful source of variation in compliance, as predicted by the depth-of-cooperation hypothesis. Depending on the degree of fit between new European rules and pre-existing national rules, governments experience varying adjustment pressures, which translate into varying degrees of compliance with the same set of regulations. Similarly, governments experience increasing incentives to defect when the rules within a specific policy area become increasingly strict, with deteriorating compliance records as a result.

While couching their results in terms other than those commonly used in the regime literature, students of EU implementation have in recent years shown that relative adjustment pressures systematically affect member states' decisions to comply. In simple terms, the greater the legal and behavioral adjustment required to conform to a rule, the less inclined EU member states are to comply. Comprehensive studies of implementation in the U.K. demonstrate that the conformity in substance and form between the requirements of EU directives and existing U.K. law shapes the degree of compliance. ${ }^{50}$ Similarly, Christoph Knill and Andrea Lenschow submit that new regulatory instruments that do not conform to existing institutional 
arrangements at the national level are more likely to meet resistance than those that do. ${ }^{51}$ Tanja Börzel concludes in a comparative study of the implementation of environmental directives in Germany and Spain that the degree of fit between EU and national policy regimes influences member states' willingness to comply. ${ }^{52}$

Interest groups and entrenched bureaucracies constitute the key mechanisms through which the requirement of behavioral change influences government compliance decisions. The means of government shirking are both foot-dragging in the implementation of EU directives and in the skewed application of rules in operation. In the economic area, national governments and subnational authorities, concerned with employment and regional development, have been sensitive to the calls from firms squeezed by increasing European competition. Identifying reasons for late implementation, the Commission stresses that it is not unusual for a government to succumb to "pressures from domestic industries who urge it to delay the transposition of EU legislation in order to keep their sectors protected for just a little bit longer." ${ }^{, 53}$ In policy areas where state authorities, rather than firms, face the greatest demands of adjustment, compliance has suffered from government resistance. EU rules that require changes in well-established administrative structures, procedures, and practices at the national level meet with resistance from bureaucracies with vested interests in existing arrangements.

Member governments seldom face identical requirements of behavioral adjustment as a result of new European rules. National regulatory traditions, and differences in the capacity of governments to export domestic regimes to the EU level, result in varying adjustment pressures on member states. For any given rule, the incentives to shirk therefore ought to vary between the member states, with implications for compliance. This pattern is identified in EU environmental policy, which is an area uniquely suited for evaluating this hypothesis. Policy development in the environmental domain has been driven by a group of progressive states (leaders) promoting their domestic standards for universal adoption, thereby pulling along a group of reluctant states (laggards) to higher levels of protection. ${ }^{54}$ The varying adjustment demands that result from this leader-laggard dynamic affect the willingness of member states to comply. This in turn contributes to the crossnational patterns in Figure 4, where environmental leaders (Denmark, the Netherlands, and Germany) are among the most compliant and environmental laggards (Italy, Spain, Portugal, and Greece) among the least compliant. ${ }^{55}$

51. See Knill and Lenschow 2000.

52. Börzel 2000. See also the contributions in Cowles, Caporaso, and Risse 2001.

53. European Commission 1996b, 8.

54. See Héritier 1995; Sbragia 1996; Liefferink and Skou Andersen 1998.

55. The leader-laggard dynamic is a pattern, not a rule; traditional environmental leaders are sometimes subject to intense adjustment pressure, when EU rules require far-reaching behavioral changes. In these cases, traditional leaders demonstrate the same propensity for non-compliance, which lends further support to the hypothesis that behavioral adjustment demands shape the degree of compliance. Börzel 2000. 
The EU's air pollution directives offer an illustrative case of how this leaderlaggard dynamic operates in a concrete policy context. ${ }^{56}$ While subject to the same set of rules, Germany and Spain experienced radically different incentives for defection. The air pollution directives were modeled on the German approach to combating environmental pollution, and therefore did not produce any kind of adjustment pressure or compliance problem for Germany. By contrast, the directives fundamentally conflicted with existing Spanish regulations, which caused Spanish authorities to refuse implementation, in view of the considerable costs involved in upgrading the Spanish system.

According to enforcement theorists, deepened cooperation and increases in the general adjustment pressure over time should result in growing compliance problems. In the EU context, an appropriate test of this hypothesis is the completion of the EU's internal market in the late 1980s and early 1990s, which added new adjustment demands to pre-existing constraints. ${ }^{57}$ By seeking to eliminate all obstacles to the free movement of goods, services, people, and capital within the EU, the internal market program struck at the nerve of the state's involvement in the economy. To legally implement and correctly apply the close to 300 legal acts of the program, governments had to refashion domestic regulatory regimes and frame new relationships with domestic economic interests, which previously had profited from state protectionism.

The increasing adjustment pressure brought palpable effects on governments' willingness to comply. In the early 1990 s, the rate of implemented internal market directives was considerably lower than the overall rate of legal implementation in the EU. ${ }^{58}$ Equally problematic, but more difficult to trace, was the uneven application of the new rules. A high-level representative of the Commission in 1995 lamented: "There is no point in having agreed to all these rules on the Single Market if they are not respected on the ground. [ . . If the [Single Market] is to work in practice, Member States must apply the rules in practice even if they come under protectionist pressure from narrow interest groups." 59 Since the internal market is the core of EU cooperation and the policy domain with the highest number of directives, the effects of this massive policy program are also visible in the cross-temporal compliance data presented in Figures 1 and 3. Low levels of implementation and skewed application of rules contributed to the increase in complaints lodged with the Commission, as well as to the doubling of the number of infringement proceedings in the first half of the 1990s. ${ }^{60}$

56. Börzel 2000.

57. For extensive accounts of this process, see Armstrong and Bulmer 1998; Tallberg 1999 a.

58. Tallberg $1999 \mathrm{a}, 125$.

59. Mogg 1996, 1.

60. Whereas the first jump in the number of proceedings around 1990 may partly have resulted from delayed effects of the enlargement to Portugal and Spain in 1986, the further increase in the number of proceedings to a level of around 1,200 in 1992 and 1993 is more directly an effect of the internal market program. 


\section{Non-compliance due to Capacity Limitations}

Existing evidence on the implementation and application of EU policy points to capacity limitations as the second major source of non-compliance. As opposed to the protracted forms of incapacity that plague many developing countries, the problems experienced by EU member states mainly result from legislative arrangements with a delaying effect on implementation, and administrative capacity gaps that can be addressed once detected. These are capacity limitations that tend to characterize domestic politics in the member states as well, and typically, "the implementation of Community legislation follows the same patterns and meets the same obstacles as the implementation of the respective national legislation."61 The description of these capacity problems draws particularly on the most extensive comparative study of EU implementation so far, edited by Heinrich Siedentopf and Jacques Ziller, conducted by ten national research teams, and consisting of detailed empirical analyses of seventeen directives, drawn from a wide set of policy areas. ${ }^{62}$

The first form of capacity limitations consists of executive inability to adapt national law to EU directives in a timely manner, because of constitutionally determined characteristics of the process of legal implementation. Samuel Krislov, Claus-Dieter Ehlermann, and Joseph Weiler even consider the constitutional position on implementation to be the primary explanation of non-compliance in the EU. ${ }^{63}$ Whereas in most member states, the executive has been granted specific legislative powers for the incorporation of EU directives, some states have maintained the same legislative arrangements that apply to national law, with the same parliamentary involvement. This increases the risk of not concluding the implementation process within the tight two-year deadline generally imposed by the Council.

In Italy, the requirement of parliamentary adoption, coupled with the high turnover rate of Italian governments, was for long the primary source of its compliance problems. ${ }^{64}$ It is the magnitude of these problems that still makes Italy the member state with the worst compliance record over the last two decades, measured in infringement proceedings (see Figure 4). The procedure for incorporating directives has subsequently been changed, with notable effects on the Italian implementation rate in recent years. ${ }^{65}$ Sweden constitutes another case in point. Of the relatively few infringement proceedings initiated against Sweden, most have their origin in the adoption of implementing acts via the same legislative procedure that applies for national law, which frequently takes longer than two years from beginning to end. ${ }^{66}$

61. Siedentopf and Hauschild 1988, 58 .

62. The results are published in two volumes: Siedentopf and Ziller 1988a and 1988b. The reference to Siedentopf and Hauschild 1988 refers to the summary of the comparative analysis.

63. Krislov, Ehlermann, and Weiler 1986.

64. See Krislov, Ehlermann, and Weiler 1986; Siedentopf and Hauschild 1988

65. European Commission 2000.

66. Tallberg 1999b. 
A related problem plagues implementation in states whose constitutional arrangements grant subnational governments partial or exclusive legislative authority in certain policy domains. In these cases, the central government has limited influence over the actual adoption of implementing acts. In Belgium, Germany, Italy, and Spain, regions boasting considerable legislative and executive competence have on occasion been reluctant to legally implement EU measures on which they have had no influence, thus contributing to the cross-national pattern in Figure $4 .{ }^{67}$ Paradoxically, the centralized state of Finland offers perhaps the best illustration of this logic. In the early years after the 1995 accession, the legislative prerogatives of the semi-autonomous Åland Islands delayed Finnish wholesale implementation of EU directives and gave rise to massive numbers of infringement proceedings. ${ }^{68}$ Once Finland found an arrangement for dealing with this problem, the number of proceedings was immediately reduced, from 290 in 1996 to 44 in $1999 .{ }^{69}$

The second capacity-related source of violations is deficiencies in a state's administrative apparatus. The country studies reported by Siedentopf and Ziller demonstrate that, in the 1980s, gaps in the quantity and quality of administrative staff caused compliance problems in Belgium, Ireland, the U.K., Italy, and Greece, whereas such gaps only arose in exceptional cases in Denmark, Germany, France, Luxembourg, and the Netherlands. ${ }^{70}$ These differences among member states in administrative capacity accord only partially with the cross-national patterns documented in Figure 4, which suggests that this factor constitutes a supplementary, rather than dominant, explanation.

Gaps in internal coordination similarly affect compliance with EU rules, especially in new member states. In many ways opposites in EU policymaking, Greece and Sweden struggled with similar coordination problems after entering the EU in 1981 and 1995, respectively. An official report on Greek EU policy concluded in 1990 that compliance during the first decade of membership had suffered from an inefficient government structure, leading to undue delays in the implementation of EU legislation. ${ }^{71}$ Only five years after accession was a special legal department created to coordinate government activity and reduce violations. In close parallel, but without the same magnitude of infringement cases as a result, Sweden still struggled in 2000 with defective routines for keeping track of implementation deadlines. $^{72}$

The severity of these forms of capacity limitations and their effects on compliance are partly dependent on the pressure exercised by EU policymaking on domestic political structures. Comprehensive policy programs tend to reinforce the impact of pre-existing capacity problems, thereby causing increases in violations. The pro-

67. Siedentopf and Hauschild 1988; interview, Commission official, March 1996.

68. European Commission 1996a.

69. European Commission 2000.

70. Siedentopf and Hauschild 1988. Spain and Portugal were not included in the study, because of their short time as members. See also Pridham 1996; Vogel and Kessler 1998.

71. Ioakimidis 1994.

72. Interview, Swedish government official, September 2000. 
gram to complete the internal market constitutes the best example. ${ }^{73}$ The pressure on member states' legislative machinery of having to legally incorporate 220 directives within an extremely limited time period was in many cases formidable. By November 1990, member states were supposed to have implemented 107 directives, by August 1992, 174, and by late 1993 all 220. Legislative delays were a defining characteristic of this process. ${ }^{74}$ As the flow of directives within this policy program came to an end, the pressure of EU activity on domestic legislative structures eased. Whereas close to seventy directives had been adopted by the Council in 1992, less than forty were adopted in both 1994 and $1995 .^{75}$ As Figure 2 shows, this reduction in legislative activity made it possible for member states to catch up with the implementation backlog in the second half of the 1990s, encouraged in this task by the Commission's persistent initiation of proceedings against laggards.

\section{The Complementarity of Enforcement and Management}

In the contemporary theoretical debate, the enforcement approach and the management approach offer rival hypotheses on the determinants of compliance. In the preceding sections of this article, I have presented empirical evidence that challenges the competing nature of these explanations. The EU compliance system reaches a high degree of effectiveness in combating violations by combining instruments of coercive enforcement with mechanisms of managerial problem solving. In addition, the EU case lends support to the privileged explanations of both approaches on why non-compliance emerges in the first place.

In this concluding section, I place the European experience in a comparative perspective and consider evidence from international regimes in a wide range of policy domains. I address three questions: Do other international regimes grant support to the proposition that compliance systems are most effective when combining enforcement and management strategies? What is particular about the EU's combination of enforcement and management mechanisms in a comparative perspective? What have been the historical preconditions for the EU's compliance system, and what is the probability that they could emerge, or be created, elsewhere?

\section{Enforcement and Management: The International Record}

The combination of compliance mechanisms in the EU takes the form of a highly developed "management-enforcement ladder"- a twinning of cooperative and coercive measures that, step by step, improve states' capacity and incentives for compliance. Simplifying slightly, this ladder has four stages: (1) preventive capacity building and rule clarification that reduce the risk of violations due to incapacity or

73. See Armstrong and Bulmer 1998; Tallberg 1999a.

74. Tallberg 1999a, 125.

75. Golub 1999, 741. 
inadvertence; (2) forms of monitoring that enhance the transparency of state behavior and expose violators; (3) a legal system that permits cases to be brought against non-compliant states and that further clarifies existing rules; and (4) deterrent sanctions as a final measure if states refuse to accept the rulings of the legal system.

If compliance systems are most effective when combining enforcement and management mechanisms, as the EU case suggests, then compliance systems that only rely on one of the strategies should demonstrate a reduced capacity to contain violations. By the same token, compliance systems that develop this complementarity over time should demonstrate an enhanced capacity to handle non-compliance. These expectations are borne out by a preliminary inventory of the international record. Early European cooperation, the global trade regime, and a range of environmental regimes demonstrate how new or refined enforcement mechanisms enhance the effectiveness of existing managerial instruments, to the benefit of the overall compliance systems. $^{76}$

Consider first the operation of the EU compliance system before the introduction of sanctions in the early $1990 \mathrm{~s}$, and the later effects of this reform on the respect for rule interpretations. As it does today, the ECJ provided authoritative interpretation of EC law. In contrast with today, however, disrespect for judgments of the ECJ could not be backed up with a threat of sanctions, but only with the initiation of new legal proceedings. The result was a substantial and ever-increasing number of disregarded decisions, often dating back many years, that governments showed little intention of implementing. Only with the new sanctioning powers under Article 228 could this body of disrespected judgments be reduced, and it is telling that one of the cases then settled concerned a fifteen-year-old complaint against France, with an eleven-year-old judgment. ${ }^{77}$ By adding the threat of sanctions as a final step in the management-enforcement ladder, the effectiveness of the entire compliance system was enhanced.

The history of the GATT/WTO similarly demonstrates how managerial elements of this compliance system were strengthened by the development of more operational enforcement mechanisms. The original GATT system employed a mainly diplomatic and cooperative approach to non-compliance, relying on ad-hoc and consensus-oriented panels, whose reports could be blocked by any of the regime's contracting parties, including the losing party. This consensus requirement proved to be paralyzing, and weakened the GATT by forcing governments to take unilateral retaliatory action, in violation of the regime. ${ }^{78}$ Growing indications of the GATT system's inability to contain non-compliance induced the signatories to couple the

76. For additional examples of the complementarity of enforcement and management, see Mitchell 1994 on the oil pollution regime; Parker 2001 on the NBC weapon control regimes; and the project on "Law and Compliance at Different Levels" coordinated by Christian Joerges and Michael Zürn. See, for example, Zürn 2000.

77. European Commission 2001.

78. Bayard and Elliott 1994. 
creation of the WTO in 1995 with a reinforced dispute-settlement mechanism. ${ }^{79}$ The new system involves stronger enforcement powers for the WTO and stronger retaliatory powers for its member states. The first years of operation suggest a higher effectiveness in addressing violations, as signified by aggrieved parties' increasing recourse to this system relative to unlawful, unilateral action. ${ }^{80}$

That compliance systems suffer in effectiveness when either management or enforcement strategies are underdeveloped is underlined by the concerns that still remain about the dispute-settlement mechanism of the WTO. Unlike the EU, "the WTO's enforcement mechanisms have neither a deterrent nor a punishing, but merely a compensatory effect, so that the non-compliant party is in fact at liberty to choose between complying with WTO law and accepting the cancellation of proportionate concessions." ${ }^{81}$ The nature of this sanctioning instrument increases the risk of non-compliance deadlocks, as illustrated by the recent U.S.-EU dispute over hormone-treated beef, where the EU accepted the validity of the WTO's decisions and the complaining parties' right to proportional compensation, yet demonstrated no intention to remove its unlawful trade embargo. In April 2000, states refused to comply with four out of the thirty-two final decisions so far handed down by WTO dispute-settlement bodies. ${ }^{82}$ Whereas the WTO today boasts a more impressive enforcement component, the design of its measure of last resort impedes the effectiveness of the overall compliance system.

Environmental regimes are generally considered to be highly reliant on problemsolving strategies, and constitute the primary source of the commonly presented examples of effective management. Recently published research suggests, however, that even environmental regimes gain from supplementing traditional managerial mechanisms with enforcement measures. The effectiveness of international environmental agreements is the topic of two collaborative volumes, one edited by David Victor, Kal Raustiala, and Eugene Skolnikoff, and the other by Edith Brown Weiss and Harold Jacobson. ${ }^{83}$ Relating explicitly to the enforcement-management debate, Victor and his colleagues find, on the basis of studies in eight major areas of environmental regulation, that "the management approach may be weakened because there are few stronger tools available when management fails." ${ }^{84}$ Whereas "[m]ost cases of actual or possible noncompliance are 'managed' through discussions and negotiations... the regimes examined in this volume that have been marked by the most extensive cooperation ... have had at their disposal powerful incentives and disincentives-tools of enforcement. When such tools have been used, they have worked, especially when the sanction has been to withdraw

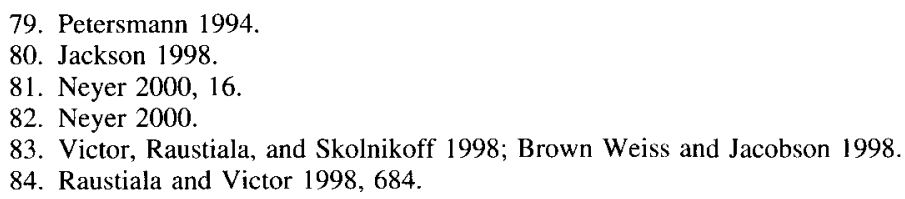


assistance." $\$ 55$ Jacobson and Brown Weiss report a similar collective finding: "While sanctions have not played a significant role in promoting compliance with the treaties we studied, they do have value as a weapon of last resort. Sanctions may still be needed as a latent threat to make other methods of achieving compliance effective. Sanctions are crucial in agreements where free-riding is possible, and could carry significant rewards."

The ozone regime is a prominent example of the complementarity of enforcement and management in the environmental domain. In this regime, a complex network of formal and informal bodies engage in forms of managerial problem solving, which include economic capacity building, technological assessment, and implementation review. Whereas these managerial efforts are effective in handling most violations, more difficult and persistent failures to comply, such as Russia's neglect of its regulatory commitments, have only been solved when associated institutions have drawn on available enforcement measures and threatened penalties. As Victor emphasizes: "[The ozone regime's non-compliance procedure] has been most effective when it blends the two approaches. Management avoids the most severe and unproductive antagonism, but the credible threat of tougher actions, including sanctions, helps ensure cooperation, especially when dealing with parties who are unswayed by management alone." 87

\section{The Institutional Design of Enforcement and Management}

What is particular about the EU's combination of enforcement and management in this comparative perspective is the operation of these functions by independent supranational institutions and empowered societal interests. As opposed to most international regimes, where the signatories themselves play a central role in executing enforcement and management functions, the EU has supranational institutions in charge of capacity building, monitoring, rule interpretation, and sanctioning, with assistance from transnational societal interests.

The question of how enforcement and management are executed receives scant attention in the key contributions of the two theoretical approaches. Chayes and Chayes play down the importance of institutional design and argue that the nature of rule interpretation is of little importance: "On the whole, it has not seemed to matter whether the dispute settlement procedure is legally required or the decision is legally binding, so long as the outcome is treated as authoritative." 88 Similarly, Downs, Rocke, and Barsoom consider the institutional form of enforcement less important: "The specific mechanism by which states punish violations is less

85. Rausiala and Victor $1998,683$.

86. Jacobson and Brown Weiss 1998, 547-548.

87. Victor 1998, 139. See also Greene 1998.

88. Chayes and Chayes 1995, 24. 
relevant to the specific relationship between depth of cooperation and enforcement than is the magnitude of enforcement." 89

This absence of attention to institutional form stands in contrast to the growing literature on the design of international legal systems. ${ }^{90}$ This literature suggests that the design of compliance systems can be conceptualized as a continuum, ranging from interstate to supranational forms of rule supervision. In the ideal-type interstate system, enforcement and management functions are executed by the states themselves; regime institutions possess no powers to act independently, and societal actors neither have access to these institutions nor enjoy the right to invoke regime rules before national courts. In the ideal-type supranational compliance system, by contrast, the parties have delegated enforcement and management powers to independent institutions, and individuals enjoy direct access to national and/or supranational legal bodies.

The EU is clearly placed at the supranational end of this continuum, whereas most international regimes operate with stronger or weaker variants of the interstate compliance system. The effects of the supranational organization of enforcement and management in the EU may be illustrated by a comparison with the global trade regime, which generally is considered institutionally well-developed, but is decidedly less supranational than the EU. I will consider one central dimension of variation in institutional design: the question of access to dispute-settlement bodies. ${ }^{91}$ Other relevant dimensions include the authority to decide over, and the power to engage in, capacity building, monitoring, and sanctioning.

The effectiveness of the EU's compliance system is closely linked to provision of access, not only to states, but also to an international commission and private litigants. ${ }^{92}$ Whereas the member states are extremely hesitant about raising cases against each other, for fear of retaliation and diplomatic inconvenience, the Commission and societal interests have no such constraints. In its position as international prosecutor, the Commission initiates a staggering number of infringement proceedings each year, with proven effectiveness in inducing compliance. Similarly, individuals seeking redress in national courts for state violations of EC law are central in making the EU's decentralized compliance system work, and contribute to the further development of European law when cases are referred to the ECJ for interpretation.

In contrast to the EU, the institutional designs of the GATT and the WTO do not provide for non-compliance actions brought by an international commission or private litigants. Instead, the key accords institute dispute-settlement mechanisms

89. Downs, Rocke, and Barsoom 1996, 386.

90. Helfer and Slaughter 1997; Yarbrough and Yarbrough 1997; Keohane, Moravesik, and Slaughter 2000; Alter 2001b.

91. For good discussions, see Keohane, Moravcsik, and Slaughter 2000; Alter 2001b.

92. An additional example that demonstrates the merits of access for private litigants is the European human rights regime. Like the EU, this regime offers both interstate and private non-compliance procedures. As in the EU, the private complaint procedure has been considerably more effective than its interstate equivalent. Helfer and Slaughter 1997. 
that offer an aggrieved state the possibility of challenging another state with non-compliance, and having the case decided by an arbitration body. Despite the absence of other means for securing each other's compliance, the parties remain reluctant to raise cases against each other. Initiation of a dispute is costly; the complaining state risks losing the case; and if it wins, retaliation might follow. The notable symmetry in the WTO between states that bring cases and states that become the objects of complaints suggests an element of retaliation in the initiation of proceedings.

The restricted forms of access to these dispute-settlement arrangements influences the number of cases brought, and thereby the capacity of the enforcement and management mechanisms of these systems to induce compliance. While comparative data should be interpreted carefully, they provide an idea of the effects of the variation in access. ${ }^{93}$ Under the GATT dispute-settlement mechanism, an average of less than five cases were initiated each year. With the establishment of the new WTO procedure, and the abolition of the state veto, the number has risen to about thirty cases per year. This should be compared to the EU record of an annual average of about 175 preliminary ruling cases, an unknown but considerably larger number of cases decided directly in national courts, and an annual average of more than 800 Commission infringement cases during the last two decades.

\section{An Inimitable or Replicable Compliance System?}

The EU's supranational features serve its compliance system well and render the combination of enforcement and management mechanisms especially effective in inducing rule conformity. It is essential to recognize that this compliance system in its present form is the product of a complex historical process of institutional development. Three factors have been particularly important in this historical evolution: the delegation of supervisory powers to the supranational institutions, these institutions' autonomous transformation of available compliance procedures, and the willingness of domestic actors to play a role in EU enforcement.

Delegation set the framework conditions for later developments by granting the Commission and the ECJ privileged functions in EU supervision, as well as a degree of discretion within these powers that enabled autonomous actions by the institutions. ${ }^{94}$ Acting on pro-integration preferences, the supranational institutions exploited their room to maneuver by strengthening the compliance system over time. The Commission improved centralized supervision by reforming the infringement procedure, opening channels for complaint-based monitoring, and introducing effective shaming and bargaining practices. The ECJ, in turn, independently con-

93. The data on the GATT, the WTO, and the preliminary ruling procedure are reported in Keohane, Moravcsik, and Slaughter 2000, based on Sands et al. 1999; the data on Commission cases emanate from Figure 3.

94. For principal-agent analyses of the supranational institutions' capacity to exert independent influence, see Pollack 1997; Stone Sweet and Caporaso 1998; Tallberg 2000b and 2002. 
verted the preliminary ruling procedure into a decentralized instrument for enforcing EC law, transformed individuals and national courts into tools of supervision, and equipped these domestic actors with effective legal remedies. But the process of empowerment worked in both directions. The Commission's ambition to turn the infringement procedure into a powerful enforcement tool would have stood little chance of success had citizens and companies not made extensive use of the complaint procedure. Similarly, the ECJ would never have been able to creatively develop the EU's compliance system had individuals not raised cases and national courts not referred cases to the European court for interpretation.

Clearly, the probability of reproducing this historical development in other international regimes is low. The emergence or creation of an effective compliance system, such as that of the EU, depends on several factors. Some are within the control of states as contracting parties, some are within the power of the international supervisory institutions themselves, and some lie beyond the control of both states and international officials. ${ }^{95}$ The required degree of convergence in multiple forms of preconditions is thus high. What the EU case illustrates, however, is the key role of states at the moment of delegation. Through institutional design, governments may either seek to replicate the EU's arrangement or create the framework conditions necessary for development of an effective compliance system. But it is questionable whether reproductions of the EU system are what most governments want for most regimes. The absence of highly constraining institutional arrangements is no historical accident. As Frederick Abbott emphasizes in his analysis of the creation of the North American Free Trade Agreement, the contracting parties were not ready to delegate far-reaching supervisory powers because of sovereignty concerns. ${ }^{96}$ Similarly, John Jackson notes: "As 'heroic' as they may appear, the dispute procedures of the WTO have a number of features that are obviously designed to 'protect sovereignty' of the WTO members, and to prevent too much power being allocated to the dispute process." 97

Though state reluctance to trade sovereignty for effective rule supervision may be the dominating trend, the European human rights regime provides an illustration of how framework conditions resembling those of the EU can in fact produce similar dynamics. ${ }^{98}$ In this regime, the European Court of Human Rights (ECHR) has raised the effectiveness of the mechanism whereby individuals may file cases with the court against governments allegedly violating human rights norms. Like the ECJ, the ECHR has exploited the autonomy inherent in the function of legal interpretation to strengthen the regime's compliance system. And just as in the EU, the interplay between complainants and court has contributed to the mutual empowerment of both categories of actors. Access to the ECHR has enabled individuals to defend their

95. Helfer and Slaughter 1997 provide a checklist for effective supranational adjudication, organized around these three categories of factors.

96. Abbott 2000.

97. Jackson 1998, 78.

98. Helfer and Slaughter 1997. 
rights and enforce compliance with regime rules. ${ }^{99}$ Simultaneously, these actions have helped the ECHR to build a high-profile docket of cases, on the basis of which it has attracted new complaints and issued interpretations that reinforce the regime and its compliance system.

Regimes in the areas of trade, environment, and human rights lend additional support to the proposition that compliance systems become most effective when combining enforcement and management strategies. What is particular about the EU in this comparative perspective is its supranational organization of enforcement and management. These results challenge the conception of enforcement and management as antithetical perspectives and competing compliance strategies. The interaction between enforcement and management instruments in the actual practices of international regimes constitutes a rich field for further research.

\section{References}

Abbott, Frederick. 2000. NAFTA and the Legalization of World Politics: A Case Study. International Organization 54 (3):519-47.

Alter, Karen J. 2000. The European Union's Legal System and Domestic Policy: Spillover or Backlash? International Organization 54 (3):489-518.

- 2001a. Establishing the Supremacy of European Law: The Making of an International Rule of Law in Europe. Oxford: Oxford University Press.

- 200lb. International Legal Systems, Regime Design and the Shadow of the Law in International Relations. Unpublished manuscript, Northwestern University, Chicago, Ill.

Alter, Karen J., and Jeannette Vargas. 2000. Explaining Variation in the Use of European Litigation Strategies: Community Law and British Gender Equality Policy. Comparative Political Studies 33(4): 452-82.

Armstrong, Kenneth, and Simon Bulmer. 1998. The Governance of the Single European Market. Manchester: Manchester University Press.

Audretsch, H. A. H. 1986. Supervision in European Community Law. 2nd ed. Amsterdam: NorthHolland.

Axelrod, Robert. 1984. The Evolution of Co-operation. London: Penguin.

Axelrod, Robert, and Robert O. Keohane. 1986. Achieving Cooperation Under Anarchy: Strategies and Institutions. In Cooperation Under Anarchy, edited by Kenneth A. Oye, 226-54. Princeton, N.J.: Princeton University Press.

Bayard, Thomas O., and Kimberly Elliott. 1994. Reciprocity and Retaliation in U.S. Trade Policy. Washington D.C.: Institute for International Economics.

Brown Weiss, Edith, and Harold K. Jacobson, eds. 1998. Engaging Countries: Strengthening Compliance with International Environmental Accords. Cambridge, Mass.: MIT Press.

Burley, Anne-Marie, and Walter Mattli. 1993. Europe before the Court: A Political Theory of Legal Integration. International Organization 47 (1):41-76.

Börzel, Tanja A. 2000. Why there is no 'Southern Problem': On Environmental Leaders and Laggards in the European Union. Journal of European Public Policy 7 (1):141-62.

- 2001. Non-Compliance in the European Union: Pathology or Statistical Artefact? Journal of European Public Policy 8 (5):803-24.

99. Before 1999, an individual first had its complaint assessed by the European Commission of Human Rights, but individuals today can turn directly to the ECHR. 
Chayes, Abram, and Antonia Handler Chayes. 1995. The New Sovereignty: Compliance with International Regulatory Agreements. Cambridge, Mass.: Harvard University Press.

Chayes, Abram, Antonia Handler Chayes, and Ronald B. Mitchell. 1998. Managing Compliance: A Comparative Perspective. In Engaging Countries: Strengthening Compliance with International Environmental Accords, edited by Edith Brown Weiss and Harold K. Jacobson, 39-62. Cambridge, Mass.: MIT Press.

Cichowski, Rachel A. 2002. Litigation, Mobilization and Governance: The European Court and Transnational Activism. Ph.D. diss., University of California, Irvine.

Conant, Lisa. 2002. Justice Contained: Law and Politics in the European Union. Ithaca, N.Y.: Cornell University Press.

Cowles, Maria Green, James Caporaso, and Thomas Risse, eds. 2001. Transforming Europe. Europeanization and Domestic Change. Ithaca, N.Y.: Cornell University Press.

Daintith, Terence C., ed. 1995. Implementing EC Law in the United Kingdom: Structure for Indirect Rule. Chichester: Wiley.

Dehousse, Renaud. 1998. The European Court of Justice: The Politics of Judicial Integration. London: Macmillan.

Dorn, A. Walter, and Andrew Fulton. 1997. Securing Compliance with Disarmament Treaties: Carrots, Sticks, and the Case of North Korea. Global Governance 3 (1):17-40.

Downs, George W., David M. Rocke, and Peter N. Barsoom. 1996. Is the Good News about Compliance Good News about Cooperation? International Organization 50 (3):379-406.

European Commission. 1996a. Thirteenth Annual Report on Monitoring the Application of Community Law (1995). COM (96) 600 Final. 28.2.1996.

1996b. The Single Market and Tomorrow's Europe: A Progress Report from the European Commission. Luxembourg: Office for Official Publications of the European Communities.

1996c. Memorandum on Applying Article 171 of the EC Treaty. Official Journal, No. C 242/6-8. 21.8.1996.

1999. Sixteenth Annual Report on Monitoring the Application of Community Law (1998). COM (99) 301 Final. 9.7.1999.

- 2000. Seventeenth Annual Report on Monitoring the Application of Community Law (1999). COM (2000) 92 Final. 23.6.2000.

2001. Eighteenth Annual Report on Monitoring the Application of Community Law (2000). COM (2001) 309 Final. 16.7.2001.

Golub, Jonathan. 1999. In the Shadow of the Vote? Decision Making in the European Community. International Organization 53 (4):733-64.

Greene, Owen. 1998. The System for Implementation Review in the Ozone Regime. In The Implementation and Effectiveness of International Environmental Commitments: Theory and Evidence, edited by David G. Victor, Kal Raustiala, and Eugene B. Skolnikoff, 89-136. Cambridge, Mass.: MIT Press.

Haas, Peter M. 1998. Compliance with EU Directives: Insights from International Relations and Comparative Politics. Journal of European Public Policy 5 (1):17-37.

Haas, Peter M., Robert O. Keohane, and Marc A. Levy, eds. 1993. Institutions for the Earth: Sources of Effective International Environmental Protection. Cambridge, Mass.: MIT Press.

Harlow, Carol, and Richard Rawlings. 1992. Pressure through Law. New York: Routledge.

Helfer, Laurence R., and Anne-Marie Slaughter. 1997. Toward a Theory of Effective Supranational Adjudication. Yale Law Journal 107 (2):273-391.

Héritier, Adrienne. 1995. "Leaders" and "Laggards" in European Clean Air Policy. In Internationalization and Economic Policy: Convergence or Diversity?, edited by Brigitte Unger and Frans Van Waarden, 278-305. Aldershot: Avebury.

Hooghe, Liesbet, ed. 1996. Cohesion Policy and European Integration: Building Multi-level Governance. Oxford: Oxford University Press.

Ioakimidis, P. C. 1994. The EC and the Greek Political System: An Overview. In Greece and EC Membership Evaluated, edited by Panos Kazakos and P. C. Ioakimidis, 139-53. New York: St. Martin's Press. 
Jackson, John H. 1998. The World Trade Organization: Constitution and Jurisprudence. London: Royal Institute of International Affairs.

Jacobson, Harold K., and Edith Brown Weiss. 1998. Assessing the Record and Designing Strategies to Engage Countries. In Engaging Countries: Strengthening Compliance with International Environmental Accords, edited by Edith Brown Weiss and Harold K. Jacobson, 511-54. Cambridge, Mass.: MIT Press.

Jönsson, Christer, and Jonas Tallberg. 1998. Compliance and Post-Agreement Bargaining. European Journal of International Relations 4 (4):371-408.

Keohane, Robert O., and Marc A. Levy, eds. 1996. Institutions for Environmental Aid: Pitfalls and Promise. Cambridge, Mass.: MIT Press.

Keohane, Robert O., Andrew Moravesik, and Anne-Marie Slaughter. 2000. Legalized Dispute Resolution: Interstate and Transnational. International Organization 54 (3):457-88.

Knill, Christoph, and Andrea Lenschow. 2000. New Concepts-Old Problems? The Institutional Constraints for the Effective Implementation of EU Environmental Policy. Paper presented at the Annual Conference of the International Studies Association, March, Los Angeles.

Krislov, Samuel, Claus-Dieter Ehlermann, and Joseph Weiler. 1986. The Political Organs and the Decision-Making Process in the United States and the European Community. In Integration through Law. Vol. 1, Book 2, edited by Mauro Cappelletti, Monica Seccombe, and Joseph Weiler, 3-110. Berlin: De Gruyter.

Levy, Marc A., Robert O. Keohane, and Peter M. Haas. 1993. Improving the Effectiveness of International Environmental Institutions. In Institutions for the Earth: Sources of Effective International Environmental Protection, edited by Peter M. Haas, Robert O. Keohane, and Marc A. Levy, 397-426. Cambridge, Mass.: MIT Press.

Liefferink, Duncan, and Mikael Skou Andersen. 1998. Strategies of the "Green" Member States in EU Environmental Policy Making. Journal of European Public Policy 5 (2):254-70.

Maher, Imelda. 1996. Limitations on Community Regulation in the UK: Legal Culture and Multi-Level Governance. Journal of European Public Policy 3 (4):577-93.

Marks, Gary. 1993. Structural Policy and Multilevel Governance in the EC. In The State of the European Community. Vol. 2. The Maastricht Debates and Beyond, edited by Alan W. Cafruny and Glenda G. Rosenthal, 391-410. Boulder, Colo.: Lynne Rienner.

McCubbins, Mathew D., and Thomas Schwartz. 1984. Congressional Oversight Overlooked: Police Patrols versus Fire Alarms. American Journal of Political Science 28 (1):165-79.

Mendrinou, Maria. 1996. Non-compliance and the European Commission's Role in Integration. Journal of European Public Policy 3(1):1-22.

Miles, Edward L., Arild Underdal, Steinar Andresen, Jørgen Wettestad, Jon Birger Skjærseth, and Elaine M. Carlin. 2002. Environmental Regime Effectiveness: Confronting Theory with Evidence. Cambridge, Mass.: MIT Press.

Mitchell, Ronald B. 1994. Intentional Oil Pollution at Sea: Environmental Policy and Treaty Compliance. Cambridge, Mass.: MIT Press.

Mitchell, Ronald B. 1999. Situation Structure and Regime Implementation Strategies. Unpublished manuscript, Stanford University, Stanford, Calif.

2000. Transparency's Three Paths of Influence. Paper presented at the Annual Conference of the International Studies Association, March, Los Angeles.

Mogg, John. 1996. Editorial. Single Market News 5:1.

Neyer, Jürgen, 2000. Domestic Limits of Supranational Legal Integration: Explaining the Relative Effectiveness of European and International Trade Policy. Paper presented at the workshop on "Comparing Compliance at the National, European and International Levels," December, European University Institute, Florence.

Olson, Mancur. 1965. The Logic of Collective Action: Public Goods and the Theory of Groups. Cambridge, Mass.: Harvard University Press.

Parker, Charles F. 2001. Controlling Weapons of Mass Destruction. An Evaluation of International Security Regime Significance. Ph.D. diss., Uppsala University. 
Petersmann, Ernst-Ulrich. 1994. The Dispute Settlement System of the World Trade Organization and the Evolution of the GATT Dispute Settlement System since 1948. Common Market Law Review 31(5):1157-244.

Pollack, Mark A. 1997. Delegation, Agency, and Agenda Setting in the European Community. International Organization 51(1): 99-134.

Pridham, Geoffrey. 1996. Environmental Policies and Problems of European Legislation in Southern Europe. South European Society and Politics 1 (1):47-73.

Raustiala, Kal, and David G. Victor. 1998. Conclusions. In The Implementation and Effectiveness of International Environmental Commitments: Theory and Evidence, edited by David G. Victor, Kal Raustiala, and Eugene B. Skolnikoff, 659-707. Cambridge, Mass.: MIT Press.

Raustiala, Kal and Anne-Marie Slaughter. 2002. International Law and Compliance. In Handbook of International Relations, edited by Walter Carlsnaes, Thomas Risse, and Beth Simmons, 538-58. London: Sage.

Sands, Philippe, Ruth Mackenzie, and Yuval Shany, eds. 1999. Manual on International Courts and Tribunals. London: Butterworths.

Sbragia, Alberta. 1996. Environmental Policy: The "Push-Pull" of Policy-Making. In Policy-Making in the European Union, edited by Helen Wallace and William Wallace, 235-55. Oxford: Oxford University Press.

Siedentopf, Heinrich, and Christoph Hauschild. 1988. The Implementation of Community Legislation in the Member States: A Comparative Analysis. In Making European Policies Work: The Implementation of Community Legislation in the Member States. Vol. 1, Comparative Syntheses, edited by Heinrich Siedentopf and Jacques Ziller, 1-87. London: Sage.

Siedentopf, Heinrich, and Jacques Ziller, eds. 1988a. Making European Policies Work: The Implementation of Community Legislation in the Member States. Vol. 1, Comparative Syntheses. London: Sage.

-1988b. Making European Policies Work: The Implementation of Community Legislation in the Member States. Vol. 2, National Reports. London: Sage.

Slaughter, Anne-Marie, Alec Stone Sweet, and Joseph H. H. Weiler, eds. 1998. The European Court and National Courts: Doctrine and Jurisprudence. Oxford: Hart Publishing.

Snyder, Francis. 1993. The Effectiveness of European Community Law: Institutions, Processes, Tools and Techniques. Modern Law Review 56 (1):19-54.

Stein, Arthur A. 1983. Coordination and Collaboration: Regimes in an Anarchic World. In International Regimes, edited by Stephen D. Krasner, 115-40. Ithaca, N.J.: Cornell University Press.

Stein, Eric. 1981. Lawyers, Judges, and the Making of a Transnational Constitution. American Journal of International Law 75 (1):1-27.

Steiner, Josephine. 1995. Enforcing EC Law. London: Blackstone Press Limited.

Stone Sweet, Alec, and Thomas L. Brunell. 1998. The European Court and the National Courts: A Statistical Analysis of Preliminary References, 1961-95. Journal of European Public Policy 5 (1):66-97.

Stone Sweet, Alec, and James A. Caporaso. 1998. From Free Trade to Supranational Polity: The European Court and Integration. In European Integration and Supranational Governance, edited by Alec Stone Sweet and Wayne Sandholtz, 92-130. Oxford: Oxford University Press.

Tallberg, Jonas. 1999a. Making States Comply: The European Commission, the European Court of Justice, and the Enforcement of the Internal Market. Ph.D. diss., Lund University.

1999b. Sverige och Efterlevnaden av EU:s Regelverk: Ett Samarbetsdilemma. In Sverige i $E U$, edited by Karl Magnus Johansson, 55-76. Stockholm: SNS Förlag.

. 2000a. Supranational Influence in EU Enforcement: The ECJ and the Principle of State Liability. Journal of European Public Policy 7 (1):104-21.

2000b. The Anatomy of Autonomy: An Institutional Account of Variation in Supranational Influence. Journal of Common Market Studies 38 (5):843-64.

2002. Delegation to Supranational Institutions: Why, How, and with What Consequences? West European Politics 25 (1):23-46. 
Underdal, Arild. 1998. Explaining Compliance and Defection: Three Models. European Journal of International Relations 4 (1):5-30.

Victor, David G. 1998. The Operation and Effectiveness of the Montreal Protocol's Non-Compliance Procedure. In The Implementation and Effectiveness of International Environmental Commitments: Theory and Evidence, edited by David G. Victor, Kal Raustiala, and Eugene B. Skolnikoff, 137-76. Cambridge, Mass.: MIT Press.

Victor, David G., Kal Raustiala, and Eugene B. Skolnikoff, eds. 1998. The Implementation and Effectiveness of International Environmental Commitments: Theory and Evidence. Cambridge, Mass: MIT Press.

Vogel, David, and Timothy Kessler. 1998. How Compliance Happens and Doesn't Happen Domestically. In Engaging Countries: Strengthening Compliance with International Environmental Accords, edited by Edith Brown Weiss and Harold K. Jacobson, 19-37. Cambridge, Mass.: MIT Press.

Weiler, Joseph H. H. 1991. The Transformation of Europe. Yale Law Journal 100:2403-83.

Weiler, Joseph H. H. 1994. A Quiet Revolution: The European Court of Justice and Its Interlocutors. Comparative Political Studies 26 (4):510-34.

World Trade Organization. 2001. Overview of the State-of-Play of WTO Disputes, March 232001. Available at (www.wto.org/english/tratop_e/dispu_e/dispu_e.htm). Accessed May 92001.

Yarbrough, Beth V., and Robert M. Yarbrough. 1992. Cooperation and Governance in International Trade: The Strategic Organizational Approach. Princeton, N.J.: Princeton University Press.

1997. Dispute Settlement in International Trade: Regionalism and Procedural Coordination. In The Political Economy of Regionalism, edited by Edward D. Mansfield and Helen V. Milner, 134-63. New York: Columbia University Press.

Young, Oran R. 1979. Compliance and Public Authority: A Theory with International Implications. Baltimore: The Johns Hopkins University Press.

1992. The Effectiveness of International Institutions: Hard Cases and Critical Variables. In Governance without Government: Order and Change in World Politics, edited by James N. Rosenau and Ernst-Otto Czempiel, 160-94. Cambridge: Cambridge University Press.

1999. Governance in World Affairs. Ithaca, N.Y.: Cornell University Press.

Zürn, Michael. 2000. Law and Compliance at Different Levels. Paper presented at the workshop on "Comparing Compliance at the National, European and International Levels," December, European University Institute, Florence. 